Integrirana zaštita pšenice u suzbijanju fitopatogene gljive Fusarium graminearum

Integrated protection of wheat against Fusarium graminearum

Matić, M., Baličević, R., Novoselović, D., Ćosić, J., Vrandečić, K.

Poljoprivreda/Agriculture

ISSN: 1848-8080 (Online)

ISSN: 1330-7142 (Print)

http://dx.doi.org/10.18047/poljo.26.1.1

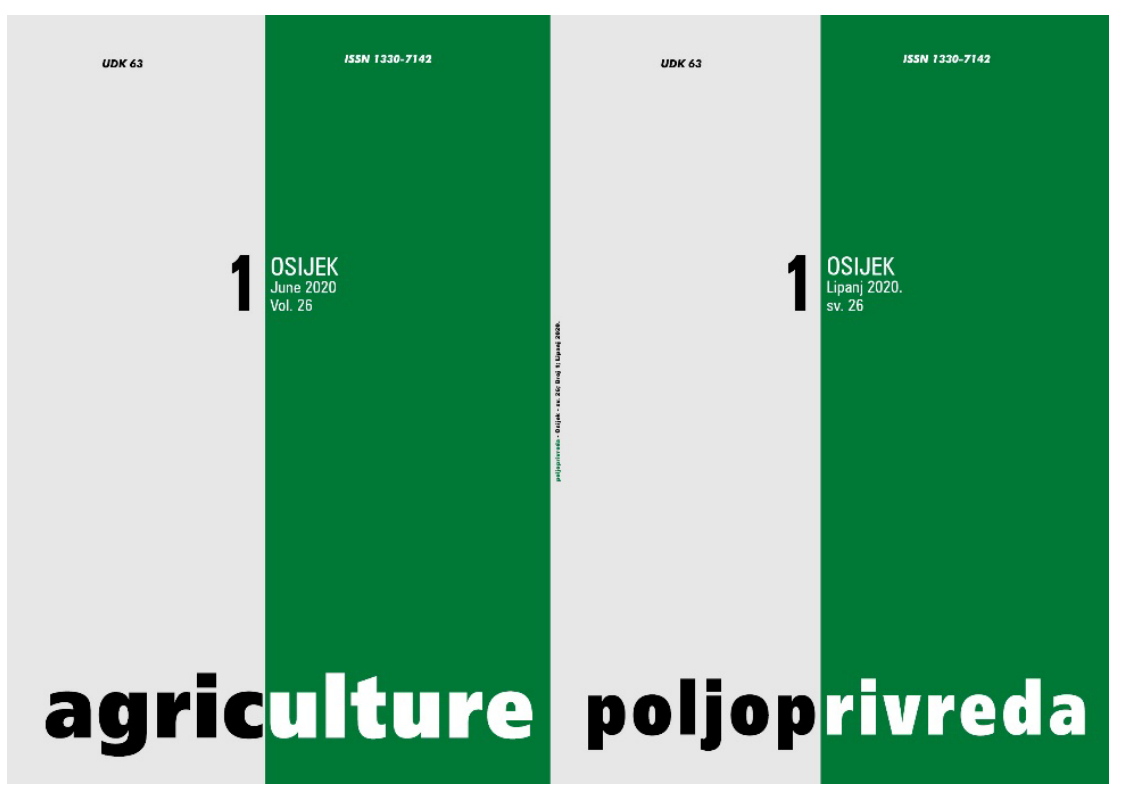

Fakultet agrobiotehničkih znanosti Osijek, Poljoprivredni institut Osijek

Faculty of Agrobiotechnical Sciences Osijek, Agricultural Institute Osijek 
ISSN 1330-7142

$U D K=632.4: 633.1$

DOI: $10.18047 /$ poljo.26.1.1

\title{
INTEGRIRANA ZAŠTITA PŠENICE U SUZBIJANJU FITOPATOGENE GLJIVE Fusarium graminearum
}

Matić, M. ${ }^{(1)}$, Baličević, R. ${ }^{(1)}$, Novoselović, D. ${ }^{(2)}$, Ćosić, J. (1), Vrandečić, K. (1)

Pregledni znanstveni članak

Scientific review

\begin{abstract}
SAŽETAK
Fuzarijska palež klasova (FHB) pšenice ekonomski je značajna bolest koja može imati nepovoljne posljedice na prinos i kvalitetu pšenice. Do danas ne postoji mjera zaštite koja osigurava potpunu zaštitu usjeva pšenice, ali kombinacija više mjera može dati dobre rezultate. Učinkovitost svake pojedine mjere pod utjecajem je okolišnih uvjeta koji prevladavaju tijekom vegetacijske sezone, a učinkovitost će ovisiti i o osjetljivosti pojedine sorte na FHB. Sve veći broj istraživanja potvrđuje kako je integrirana zaštita bilja (IZB) ključ za što uspješniju borbu protiv FHBa. Kako bi primijenjene mjere zaštite bile što uspješnije, od iznimne je važnosti dobro poznavati uzročnika bolesti, njegov životni ciklus i ekologiju. Budući da je F. graminearum dominantni uzročnik FHB-a na području Republike Hrvatske, osobiti naglasak je stavljen na sve dostupne mjere zaštite u njegovu suzbijanju.
\end{abstract}

Ključne riječi: fuzarijske bolesti, pšenica, prognoza, biološko suzbijanje

\section{UVOD}

Pšenica (Triticum spp.) je osnovna ratarska kultura na području Europe, a u kontekstu svjetskih razmjera uzgoj pšenice zauzima najveće površine u odnosu na bilo koju drugu biljku koja se uzgaja kao prehrambena namirnica (Langer i sur., 2014.). Fuzarijska palež klasova (FHB) ekonomski je značajna bolest koja se javlja gotovo kod svih žitarica, a veliki gubitci mogu se javiti upravo u proizvodnji pšenice. Najčešći i najvirulentniji uzročnici FHB-a su vrste Fusarium graminearum Schwabe (Gibberella zeae Schwein. Petch.) i Fusarium culmorum (Wm. G. Sm.) Sacc. (Dweba i sur., 2017.), čija je geografska distribucija povezana $s$ uvjetima klime, prije svega $s$ temperaturom i vlagom. Na području Republike Hrvatske dominantni uzročnik FHB-a pšenice je vrsta $F$. graminearum (Ćosić i sur., 2004.), a zaraza ovom gljivom može imati nepovoljne posljedice na prinos i kvalitetu pšenice. Gubitci prinosa u proizvodnji pšenice javljaju se kao posljedica sterilnosti zaraženih klasova ili zbog smanjene veličine zaraženih zrna. Osim na prinos, zaraza utječe i na kvalitetu pšenice. Zaražena su zrna sitnija i smežurana, a zaraza može uzrokovati i gubitke u nekim tehnološkim svojstvima, kao što su udio proteina, količina škroba i vlažnoga glutena te sedimentacijska vrijednost (Siuda i sur., 2010.). Zaraza utječe na smanjenje kvalitete pšenice i zbog sposobnosti gljive za stvaranje mikotoksina, koji mogu uzrokovati ozbiljne zdravstvene probleme u ljudi i životinja (Agostinelli i sur., 2012.). Najčešći i toksikološki najvažniji mikotoksini vrste $F$. graminearum su deoksinivalenol (DON), nivalenol (NIV) i zearalenon (ZEA) (Stępień i Chełkowski, 2010.), a potvrđena je pozitivna korelacija između intenziteta bolesti i količine DON-a u zrnu (Góral i sur., 2019.).

\section{ŽIVOTNI CIKLUS VRSTE F. GRAMINEARUM POVEZAN S RAZVOJEM FHB-a}

Životni ciklus vrste $F$. graminearum uključuje izmjenu nespolnoga i spolnog stadija. Fitopatogena gljiva

(1) Magdalena Matić, mag. biol. (maticm@fazos.hr), izv. prof. dr. sc. Renata Baličević, prof. dr. sc. Jasenka Cosić, prof. dr. Sc. Karolina Vrandečić - Sveučilište Josipa Jurja Strossmayera u Osijeku, Fakultet agrobiotehničkih znanosti Osijek, Vladimira Preloga 1, 31000 Osijek, Hrvatska, (2) Dr. sc. Dario Novoselović - Poljoprivredni institut Osijek, Južno predgrađe 17, 31000 Osijek, Hrvatska 
F. graminearum u nespolnome stadiju razvija samo srpasto povijene makrokonidije, koje nastaju u blijedo narančastim sporodohijama (Jurković i sur., 2016.). Tijekom vegetacije, primarna se zaraza vrši upravo makrokonidijama. Pri kraju vegetacije javlja se spolni stadij (Gibberella zeae Schwein. Petch.) u obliku peritecija koje sadrže veliki broj askusa s askosporama, a one također mogu vršiti zarazu. Nakon žetve, F. graminearum prezimljuje u tlu na zaraženim biljnim ostatcima domaćina u obliku micelija ili peritecija, koji predstavljaju izvor zaraze u sljedećoj vegetaciji. Vjetar i kiša omogućuju širenje spora, a time i širenje zaraze na sve veća područja. Do zaraze pojedinih klasova može doći od faze cvatnje pa sve do faze sazrijevanja zrna, iako je faza cvatnje najosjetljivija razvojna faza (Bai i Shaner, 1994.). U povoljnim uvjetima spore kliju u micelij na prašnicima ili tučku te postupno inficiraju sve dijelove cvijeta, odnosno klasića, ometajući normalno formiranje zrna (Jurković i sur., 2016.). Na početku zaraze na pljevicama je moguće uočiti sitne zelenkastosmeđe, vodenaste pjege, a razvojem bolesti dolazi do blijeđenja pojedinih klasića ili pak blijeđenja cijeloga klasa.

\section{MJERE ZAŠTITE U SUZBIJANJU FHB-a}

Mjere zaštite koje se koriste u suzbijanju uzročnika paleži klasova mogu se prema načinu djelovanja podijeliti na neizravne i izravne mjere zaštite. Neizravne mjere zaštite uključuju agrotehničke i administrativne mjere te prognozne modele, dok se u izravne mjere ubrajaju mehaničke, biotehničke, biološke te kemijske mjere. Do danas ne postoji mjera kojom je moguća potpuna zaštita usjeva pšenice, ali kombinacija više mjera zaštite može dati dobre rezultate. Učinkovitost svake pojedine mjere pod utjecajem je okolišnih uvjeta koji prevladavaju tijekom vegetacijske sezone, a učinkovitost će ovisiti i o osjetljivosti pojedine sorte na FHB. Sve veći broj istraživanja potvrđuje kako je integrirana zaštita bilja (IZB) ključ za što uspješniju borbu protiv FHB-a (McMullen i sur., 2008.). Osnovna namjena IZB-a jest smanjenje upotrebe kemijskih sredstava za zaštitu bilja na najmanju moguću razinu, a prednost se daje ekološki i toksikološki prihvatljivijim mjerama zaštite. Kemijske mjere zaštite koriste se samo u slučajevima kada se agrotehničkim mjerama ne mogu spriječiti značajne gospodarske štete.

\section{AGROTEHNIČKE MJERE ZAŠTITE}

Agrotehničke mjere zaštite predstavljaju važnu i neizostavnu sastavnicu IZB-a kojom se održava zdravlje usjeva pšenice i smanjuje količina inokuluma koji pridonosi širenju bolesti. Agrotehničke mjere zaštite uključuju plodored, obradu tla, gustoću sjetve, sjetvu otpornih ili visokotolerantnih sorata, sjetvu sorata s agronomskim i morfološkim svojstvima nepovoljnim za razvoj FHB-a $\mathrm{i} \mathrm{dr}$.

\section{PLODORED, OBRADA TLA I GUSTOĆA SJETVE}

Vrste roda Fusarium sposobne su preživjeti na zaraženim biljnim ostatcima nakon žetve. Stoga se rizik od zaraze može povezati $\mathrm{s}$ količinom zaraženih biljnih ostataka u tlu (Bateman i sur., 2007.). Naime, pojava i intenzitet bolesti veći su kod usjeva posijanih nakon kukuruza, a manji kod usjeva koji prethode soji (Dill-Macky i Jones, 2000.). Uvažavajući ove činjenice, potrebno je izbjegavati uzak plodored pšenice i kukuruza. Također, uzgoj usjeva kao što su lan i lucerna može značajno smanjiti količinu inokuluma u tlu jer većina parazita gubi sposobnost razmnožavanja u uvjetima odsustva domaćina (Shah i sur., 2018.). Obrada tla, kojom se zaoravaju zaraženi biljni ostatci, također može pozitivno utjecati na smanjenje zaraze i smanjenu kontaminaciju zrna mikotoksinima (Schaafsma i sur., 2005.; Vrandečić i sur., 2019.). Manji broj biljaka po jedinici površine također može pozitivno utjecati na smanjenje zaraze, jer manja gustoća sklopa smanjuje vlažnost koja pogoduje razvoju bolesti (Ćosić i sur., 2006.).

\section{SUZBIJANJE ALTERNATIVNIH DOMAĆINA}

Osim kultiviranih biljaka, izvor zaraze mogu biti i brojne korovne vrste. Budući da se $F$. graminearum javlja kao fakultativni parazit na mnogim korovnim biljkama (llić i sur., 2012.), one kao alternativni domaćini predstavljaju važan izvor inokuluma. Čak četrnaest vrsta roda Fusarium izolirano je s korovnih biljaka i biljnih ostataka $s$ različitih lokacija na području istočne Hrvatske (Poštić i sur., 2012.).

\section{OPLEMENJIVANJE NA FHB OTPORNOST}

Brojni autori ističu kako je upravo oplemenjivanje na otpornost najučinkovitija mjera zaštite i prevencije pojave i intenziteta FHB-a (Buerstmayr i sur., 2002.; Steiner i sur., 2017.). Do danas je poznato i opisano pet različitih tipova otpornosti (Mesterházy i sur., 1999.), a najistraživaniji su Tip I (otpornost na početnu zarazu) i Tip II (otpornost na širenje parazita od početnoga mjesta zaraze do širenja zaraze po cijelome klasu). Cilj oplemenjivanja na FHB otpornost jest stvaranje sorata koje pokazuju vrlo malo simptoma bolesti i kod kojih je akumulacija mikotoksina u zrnu mala čak i ako su pritisak zaraze i gustoća inokuluma u okolišu visoki (Buerstmayr i sur., 2009.). Sorte koje u određenome području daju visoki prinos i zadovoljavajuću kvalitetu su najčešće vrlo osjetljive. Stoga bi se oplemenjivački programi trebali usredotočiti na povezivanje svojstva visokoga prinosa i kvalitete $s$ visokom otpornošću (Buerstmayr i sur., 2009.). Do danas ne postoje sorte za koje se može reći da su u potpunosti otporne, a da pri tome imaju i dobra agronomska svojstva. Razlog tome je što se otpornost na FHB nasljeđuje kvantitativno (Bai i Shaner, 2004.), što uvjetuje da je proces selekcije iznimno dugotrajan i skup. Ipak, razlike u otpornosti između sorata postoje, te bi proizvođači trebali birati sorte koje su se u njihovu području uzgoja pokazale otpornijima. 


\section{SJETVA SORATA S AGRONOMSKIM I MORFOLOŠKIM SVOJSTVIMA NEPOVOLJNIM ZA RAZVOJ FHB-a}

Određena agronomska i morfološka svojstva (otpornost na polijeganje, visina biljke i cvatnja) povezana su s mehanizmima pasivne otpornosti na FHB. Istraživanjima u uvjetima prirodne zaraze utvrđen je značajno veći intenzitet bolesti kod nižih genotipova (Buerstmayr i sur., 2000.), a nakupljanje DON-a u zrnu veće je u slučaju polijeganja usjeva (Nakajima i sur., 2008.).

Tijekom cvatnje pšenice dolazi do otvaranja pljevica, izduživanja prašničkih niti i izbacivanja prašnika. Ponekad tijekom cvatnje ne dođe do potpunoga otvaranja pljevica, pa prašnici ostaju zaglavljeni unutar pojedinoga cvjeta. U tome slučaju govorimo o retenciji prašnika. Pretpostavilo se kako bi povećana retencija prašnika mogla biti povezana s većim intenzitetom zaraze, jer prašnici sadrže spojeve (glicin betain i kolin) koji potiču primarnu zarazu (Strange i Smith, 1971.), tj. predstavljaju početni izvor hranjivih tvari za parazita. Danas su dostupna brojna istraživanja koja potvrđuju kako je intenzitet zaraze povezan $s$ većom retencijom prašnika unutar cvjetova (He i sur., 2016.).

\section{PROGNOZNI MODELI}

Prognozni modeli razvijaju se s ciljem procjene vjerojatnosti pojave, odnosno rizika pojave određene bolesti na određenome mjestu i u određeno vrijeme. Model koji bi mogao predvidjeti vrijeme pojave FHB-a mogao bi poslužiti kao vrlo koristan alat u sklopu IZB-a od FHB-a. lako FHB uzrokuje velike gubitke prinosa i kvalitete pšenice, pojava i intenzitet zaraze ovisni su 0 klimatskim uvjetima, te mogu značajno varirati ovisno 0 godini i različitim lokacijama. Ovisnost pojave zaraze 0 vlažnome i toplom vremenu te relativno kratko razdoblje osjetljivosti pšenice na zarazu čine FHB vrlo prikladnim za modeliranje.

Postoje dva glavna pristupa u razvoju prognoznih modela za FHB. Jedan se pristup zasniva na predviđanju simptoma bolesti i prisutnosti zaraženih zrna, a drugi na predviđanju nakupljanja mikotoksina u zrnu (Schaafsma i Hooker, 2007.). Modeli predviđanja bolesti uglavnom se temelje na kombinaciji utjecaja osjetljivosti domaćina, količini i patogenosti inokuluma i klimatskim uvjetima (Xu, 2003.). Prognozni modeli nastaju matematičkim modeliranjem, a podatci koji se koriste (agronomske i okolišne varijable) pri izradi modela prikupljeni su iz kontroliranih laboratorijskih i terenskih istraživanja (Rossi i sur., 2003.). Do danas je razvijeno nekoliko modela koji omogućuju uvid u stanje na terenu te sadrže naputke za primjenu fungicida samo kada je to uistinu potrebno i opravdano na temelju rizika od pojave bolesti. U Švicarskoj je razvijen prognozni model pod nazivom FusaProg (Musa i sur.,
2007.) koji se koristi za predviđanje rizika nakupljanja mikotoksina DON-a u zrnu. U Kanadi je razvijen sličan model pod nazivom DONcast (Prandini i sur., 2009.), a u SAD-u prognozni model za procjenu rizika pojave FHB-a (Prandini i sur., 2009.). Navedeni modeli mogu značajno smanjiti gubitke prinosa tako što proizvođačima omogućuju donošenje pravovremenih odluka 0 potrebi i vremenu primjene fungicida.

Trenutno, u Republici Hrvatskoj nije razvijan nijedan ovakav model za predviđanje pojave FHB-a ili predviđanje nakupljanja mikotoksina u zrnu. Ipak, prognoza pojave bolesti vrši se u sklopu izvještajno-prognoznih poslova (IPP-a).

\section{BIOLOŠKE MJERE ZAŠTITE}

Kako bi se smanjila uporaba sintetičkih, kemijskih fungicida, sve se više teži pronalasku alternativnih metoda u zaštiti bilja. Jedna je od mogućih alternativa upravo biološko suzbijanje različitih uzročnika bolesti bilja. Biološko suzbijanje u kontekstu smanjenja intenziteta i pojave FHB-a može uključivati primjenu antagonističkih mikroorganizama i produkata njihovog metabolizma, kao i primjenu eteričnih ulja. Važnost biološkoga suzbijanja posebno dolazi do izražaja u sklopu IZB-a, gdje se prednost daje nekemijskim, ekološki i toksikološki prihvatljivijim mjerama zaštite bilja. Djelovanje antagonističkih mikroorganizama u suzbijanju $F$ graminearum može biti rezultat izravnih interakcija (mikoparazitizam, antibioza, kompeticija za prostor i hranjive tvari) ili neizravnih interakcija (inducirana rezistentnost biljke domaćina). Biološko se suzbijanje u kontekstu FHB-a može primijeniti tijekom više razvojnih faza pšenice: tretman biljnih ostataka nakon vegetacije, tretman klasa i tretman tijekom skladištenja za detoksikaciju zrna. Budući da F. graminearum prezimljuje u tlu na zaraženim biljnim ostatcima, antagonistički se mikroorganizmi mogu primijeniti nakon vegetacije kako bi smanjili količinu inokuluma. Za nekoliko je antagonističkih mikroorganizama, kao što su Trichoderma harzianum (Fernandez, 1992.), Microsphaeropsis sp. (Bujold i sur., 2001.) i Clonostachys rosea (Palazzini i sur., 2013.) dokazano kako inhibiraju stvaranje peritecija i askospora na zaraženim biljnim ostatcima. Antagonistički se mikroorganizmi mogu koristiti i za tretman klasa, čime izravno djeluju na suzbijanje parazita i tako smanjuju pojavu i intenzitet bolesti, a optimalno je vrijeme primjene antagonističkih mikroorganizama za tretman klasa tijekom cvatnje. $S$ klasova pšenice izolirane su brojne vrste bakterija i gljiva koje pokazuju antagonističko djelovanje protiv $F$. graminearum, od kojih su neke pokazale dobre rezultate u smanjenju intenziteta zaraze $\mathrm{i}$ količine mikotoksina $\mathrm{u}$ istraživanjima in vitro $\mathrm{i}$ in situ te istraživanjima u staklenicima i na polju (Tablica 1). 
Tablica 1. Bakterije i gljive izolirane s prašnika pšenice s antagonističkim djelovanjem protiv Fusarium graminearum

Table 1. Bacteria and fungi isolated from wheat anthers with antagonistic properties against Fusarium graminearum

\begin{tabular}{|l|c|}
\hline $\begin{array}{l}\text { Vrsta antagonističkog mikroorganizma } \\
\text { Type of antagonistic microorganism }\end{array}$ & \multicolumn{1}{|c|}{$\begin{array}{c}\text { Izvori } \\
\text { References }\end{array}$} \\
\hline Bakterije/Bacteria & Zhao i sur., 2014. \\
\hline Bacillus subtilis (soj/strain SG6) & Palazzini i sur., 2016. \\
\hline B. subtilis (soj/strain RC 218) i Brevibacillus sp. (soj/strain RC 263) & Palazzini i sur., 2007. \\
\hline Streptomyces sp. (soj/strain BRC87B) & Schisler i sur., 2006. \\
\hline Pseudomonas sp. (soj/strain AS 64.4) & \\
\hline Gljive/Fungi & Schisler i sur., 2002. \\
\hline Cryptococcus sp. (soj/strain OH 71.4) i Cryptococcus nodaensis (soj/strain OH 182.9) & \\
\hline
\end{tabular}

Antagonistički mikroorganizmi koji se koriste tijekom skladištenja imaju za cilj smanjiti razvoj parazita te smanjiti stvaranje i nakupljanje mikotoksina. Istraživanjima in vitro dokazano je kako određeni bakterijski sojevi uzrokuju značajno smanjenje rasta gljive $F$. graminearum te stvaranja mikotoksina, od kojih je vrsta $B$. amyloliquefaciens (soj WPS4-1) pokazala najbolje djelovanje (Shi i sur., 2014.).

Ipak, primjena antagonističkih mikroorganizama u sklopu biološke kontrole FHB-a nailazi na puno preprjeka i izazova. Unatoč brojnim istraživanjima o primjeni antagonističkih mikroorganizama u kontroli FHB-a do danas su na svjetskome tržištu dostupna samo dva sredstva koja se mogu koristiti u tu svrhu, Polyversum ${ }^{\circledR}$ (na bazi gljive Pythium oligandrum) i Cerall $®$ (na bazi bakterije Pseudomonas chlororaphis) (Comby i sur., 2017.). S druge strane, na tržištu nije dostupno niti jedno sredstvo koje bi se moglo koristiti za smanjenje stvaranja i nakupljanja mikotoksina u zrnu. Razvoj i komercijalizacija antagonističkih mikroorganizama kao biofungicida i dalje ostaju dugotrajni i složeni procesi, jer učinkovitost u laboratorijima i staklenicima ne mora rezultirati i uspjehom na polju.

Biljke proizvode veliki broj različitih metabolita bilo kao dio normalnoga razvoja bilo kao odgovor na abiotički ili biotički stres. Eterična ulja su samo jedan od primjera brojnih metabolita koji se mogu koristiti kao alternativa kemijskim mjerama zaštite bilja. Eterična ulja posjeduju antifungalna, antibakterijska i antivirusna svojstva (Palfi i sur., 2019.). Zbog antimikrobnoga djelovanja mogu se koristiti u suzbijanju štetnih mikroorganizama i tako biti zamjena kemijskih mjera zaštite. Ipak, većina istraživanja koja potkrjepljuju ovaj navod temeljena je na istraživanjima in vitro. Stoga su potrebna daljnja istraživanja njihova djelovanja u uvjetima na polju, istraživanja 0 njihovim mehanizmima djelovanja i toksikološkim svojstvima. U kontekstu suzbijanja FHB-a, eterična se ulja mogu koristiti izravno za suzbijanje rasta parazita ili u kontroli stvaranja i nakupljanja mikotoksina. Eterična ulja timijana i metvice pokazala su značajan negativan utjecaj na porast micelija gljive F. graminearum (Ćosić i sur., 2010.). Eterično ulje klinčićevca pokazalo je najbolje rezultate u smanjenju nakupljanja mikotoksina DON i ZEA u zrnu (Marín i sur., 2004.). Potrebno je naglasiti kako biološka aktivnost eteričnih ulja ovisi o kemijskome sastavu njihovih komponenti, koji je pak određen vrstom i zemljopisnim podrijetlom biljke, primijenjenim koncentracijama, okolišnim uvjetima i agrotehničkom praksom (Ćosić i sur., 2014.).

\section{KEMIJSKE MJERE ZAŠTITE}

Upotreba fungicida u sklopu IZB-a u suzbijanju uzročnika FHB-a mora biti svedena na minimum, a prednost se daje nekemijskim mjerama zaštite. Ako nekemijske mjere nisu dovoljne i fungicidi postanu jedina opcija, njihovu primjenu treba ograničiti na najmanju moguću razinu. Postoje brojni izazovi povezani s primjenom fungicida u suzbijanju pojave i intenziteta FHB-a i smanjenju nakupljanja mikotoksina (McMullen i sur., 2012.). Jedan od izazova je nejednako vrijeme cvatnje svih biljaka na polju, što bi značilo da su za uspješno djelovanje potrebne višestruke primjene, što je u sklopu IZB-a nepoželjno. Također, čest je slučaj da se period za uspješnu primjenu fungicida poklopi s nepovoljnih vremenskim prilikama, čime se sprječava primjena ili smanjuje njezina djelotvornost, a teško je i postići cjelovitu pokrivenost i zadržavanje fungicida na klasu. Osim zaštite okoliša, jedan od razloga zbog kojih se sve više pribjegava nekemijskim mjerama zaštite jest i pojava rezistentnosti gljiva i pseudogljiva na aktivne tvari zbog prekomjerne ili višestruke primjene fungicida $s$ istim mehanizmom djelovanja.

\section{ZAKLJUČAK}

Brojnost vrsta unutar roda Fusarium i njihova raznolikost, kao i široki spektar različitih bolesti koje uzrokuju, čine ovaj rod neiscrpnim područjem istraživanja. Četiri vrste roda Fusarium nalaze se među deset najvažnijih biljnih parazita na temelju njihova ekonomskoga značenja (Dean i sur., 2012.). Glavni je uzročnik FHB-a na području Republike Hrvatske vrsta $F$. graminearum. Unatoč svim dostupnim mjerama zaštite, može uzrokovati velike gubitke prinosa i kvalitete pšenice. Dostupne zaštitne mjere, koje omogućuju zaštitu pšenice, uključuju agro- 
tehničke, biološke i kemijske mjere, iako do danas ne postoji mjera koja bi osigurala potpunu zaštitu. U integriranoj zaštiti i proizvodnji pšenice pri izboru mjera zaštite prednost se daje nekemijskim, ekološki i toksikološki prihvatljivijim mjerama. Jedna od učinkovitijih, ali vrlo zahtjevna mjera zaštite, jest stvaranje genetski otpornih sorata. Kombiniranje otpornih ili tolerantnih sorata s drugim mjerama zaštite može biti učinkovit pristup zaštite i prevencije pojave i intenziteta FHB-a. Biološko suzbijanje koje uključuje primjenu antagonističkih mikroorganizama i produkata njihova metabolizma također pokazuje obećavajuće rezultate u zaštiti pšenice. Veliki interes za biološku kontrolu i sve bolje razumijevanje mehanizama djelovanja antagonističkih mikroorganizama u suzbijanju FHB-a u budućnosti će rezultirati razvojem učinkovitih, ekološki i toksikološki prihvatljivih sredstava za zaštitu bilja. Takva sredstva mogla bi zamijeniti kemijske fungicide, jer se na svjetskoj razini bilježi trend pada registracije novih djelatnih tvari kemijskoga podrijetla, a sve je veći broj odobrenih djelatnih tvari prirodnoga podrijetla.

\section{ZAHVALA}

Ovaj rad financirala je Hrvatska zaklada za znanost u sklopu projekta IP-2016-06-2178 i Znanstveni centar izvrsnosti za bioraznolikost i molekularno oplemenjivanje bilja (ZCI CroP-BioDiv).

\section{LITERATURA}

1. Agostinelli, A. M., Clark, A. J., Brown-Guedira, G., \& Van Sanford, D. A. (2012). Optimizing phenotypic and genotypic selection for Fusarium head blight resistance in wheat. Euphytica, 186(1), 115-126. https://doi.org/10.1007/s10681-011-0499-6

2. Bai, G., \& Shaner, G. (1994). Scab of wheat: prospects for control. Plant disease, 78(8), 760-766.

3. Bai, G., \& Shaner, G. (2004). Management and resistance in wheat and barley to Fusarium head blight. Annual Review of Phytopathology, 42, 135-161. https://doi.org/10.1146/annurev.phyto.42.040803.140340

4. Bateman, G. L., Gutteridge, R. J., Gherbawy, Y., Thomsett, M. A., \& Nicholson, P. (2007). Infection of stem bases and grains of winter wheat by Fusarium culmorum and F. graminearum and effects of tillage method and maize-stalk residues. Plant Pathology, 56(4), 604-615. https://doi.org/10.1111/j.1365-3059.2007.01577.x

5. Buerstmayr, H., Ban, T., \& Anderson, J. A. (2009). QTL mapping and marker assisted selection for Fusarium head blight resistance in wheat: a review. Plant Breeding, 128(1), 1-26.

https://doi.org/10.1111/j.1439-0523.2008.01550.x

6. Buerstmayr, H., Lemmens, M., Hartl, L., Doldi, L., Steiner, B., Stierschneider, M., \& Ruckenbauer, P. (2002). Molecular mapping of OTLs for Fusarium head blight resistance in spring wheat. I. Resistance to fungal spread (Type II resistance). Theoretical and Applied Genetics, 104(1), 84-91.

https://doi.org/10.1007/s001220200009
7. Buerstmayr, H., Steiner, B., Lemmens, M., \& Ruckenbauer, P. (2000). Resistance to Fusarium head blight in winter wheat: heritability and trait associations. Crop Science, 40(4), 1012-1018. https://doi.org/10.1007/s001220200009

8. Bujold, I., Paulitz, T. C., \& Carisse, 0. (2001). Effect of Microsphaeropsis sp. on the production of perithecia and ascospores of Gibberella zeae. Plant Disease, 85(9), 977-984.

https://doi.org/10.1094/PDIS.2001.85.9.977

9. Comby, M., Gacoin, M., Robineau, M., Rabenoelina, F., Ptas, S., Dupont, J., Profizi, C., \& Baillieul, F. (2017). Screening of wheat endophytes as biological control agents against Fusarium head blight using two different in vitro tests. Microbiological Research, 202, 11-20. https://doi.org/10.1016/j.micres.2017.04.014

10. Ćosić, J., Vrandečić, K., \& Jurković, D. (2014). The Effect of Essential Oils on the Development of Phytopathogenic Fungi. In N., Sharma (Ed.) Biological Controls for Preventing Food Deterioration: Strategies for Pre-and Postharvest Management. John Wiley \& Sons, Ltd.

11. Ćosić, J., Vrandečić, K., \& Svitlica, B. (2004). Fusarium vrste izolirane s pšenice i kukuruza u istočnoj Hrvatskoj. Poljoprivreda, 10(1), 5-8.

12. Ćosić, J., Vrandečić, K., Novoselović, D., Drezner, G., \& Jurković, D. (2006). Influence of planting density and planting date on the occurence of Fusarium root rot on winter wheat - a phytosanitary food chain problem. Cereal Research Communications, 34(1), 769-772.

13. Ćosić, J., Vrandečić, K., Poštić, J., Jurković, D., \& Ravlić, M. (2010). In vitro antifungal activity of essential oils on growth of phytopathogenic fungi. Poljoprivreda, 16(2), 25-28.

14. Dean, R., Van Kan, J. A., Pretorius, Z. A., Hammond Kosack, K. E., Di Pietro, A., Spanu, P. D., Rudd, J. J., Dickman, M., Kahmann, R., Ellis, J., \& Foster, G. D. (2012). The Top 10 fungal pathogens in molecular plant pathology. Molecular Plant Pathology, 13(4), 414-430. https://doi.org/10.1111/j.1364-3703.2011.00783.x

15. Dill-Macky, R., \& Jones, R. K. (2000). The effect of previous crop residues and tillage on Fusarium head blight of wheat. Plant Disease, 84(1), 71-76. https://doi.org/10.1094/PDIS.2000.84.1.71

16. Dweba, C. C., Figlan, S., Shimelis, H. A., Motaung, T. E., Sydenham, S., Mwadzingeni, L., \& Tsilo, T. J. (2017). Fusarium head blight of wheat: Pathogenesis and control strategies. Crop Protection, 91, 114-122. https://doi.org/10.1016/j.cropro.2016.10.002

17. Fernandez, M. R. (1992). The effect of Trichoderma harzianum on fungal pathogens infesting wheat and black oat straw. Soil Biology and Biochemistry, 24(10), 1031-1034. https://doi.org/10.1016/0038-0717(92)90032-S

18. Góral, T., Wiśniewska, H., Ochodzki, P., Nielsen, L., Walentyn-Góral, D., \& Stępień, Ł. (2019). Relationship between Fusarium Head Blight, Kernel Damage, Concentration of Fusarium Biomass, and Fusarium Toxins in Grain of Winter Wheat Inoculated with Fusarium culmorum. Toxins, 11(1), 2. https://doi.org/10.3390/toxins 11010002 
19. He, X., Singh, P. K., Dreisigacker, S., Singh, S., Lillemo, M., \& Duveiller, E. (2016). Dwarfing genes Rht-B1b and Rht-D1b are associated with both type I FHB susceptibility and low anther extrusion in two bread wheat populations. PLoS One, 11(9), 0162499. https://doi.org/10.1371/journal.pone.0162499

20. Ilić, J., Ćosić, J., Jurković, D., \& Vrandečić, K. (2012). Pathogenicity of Fusarium spp. isolated from weeds and plant debris in eastern Croatia to wheat and maize. Poljoprivreda, 18(2), 7-11.

21. Jurković, D., Ćosić, J., \& Vrandečić, K. (2016). Pseudogljive i gljive ratarskih kultura. Poljoprivredni fakultet u Osijeku, Sveučilište Josipa Jurja Strossmayera u Osijeku, Osijek.

22. Langer, S. M., Longin, C. F. H., \& Würschum, T. (2014). Flowering time control in European winter wheat. Frontiers in Plant Science, 5, 537. https://doi.org/10.3389/fpls.2014.00537

23. Marín, S., Velluti, A., Ramos, A. J., \& Sanchis, V. (2004). Effect of essential oils on zearalenone and deoxynivalenol production by Fusarium graminearum in non-sterilized maize grain. Food Microbiology, 21(3), 313-318. https://doi.org/10.1016/j.fm.2003.08.002

24. McMullen, M., Bergstrom, G., De Wolf, E., Dill-Macky, R., Hershman, D., Shaner, G., \& Van Sanford, D. (2012). A unified effort to fight an enemy of wheat and barley: Fusarium head blight. Plant Disease, 96(12), 1712-1728. https://doi.org/10.1094/PDIS-03-12-0291-FE

25. McMullen, M., Halley, S., Schatz, B., Meyer, S., Jordahl, J., \& Ransom, J. (2008). Integrated strategies for Fusarium head blight management in the United States. Cereal Research Communications, 36(6), 563-568. https://doi.org/10.1556/CRC.36.2008.Suppl.B.45

26. Mesterházy, Á., Bartók, T., Mirocha, C. G., \& Komoroczy, R. (1999). Nature of wheat resistance to Fusarium head blight and the role of deoxynivalenol for breeding. Plant Breeding, 118(2), 97-110. https://doi.org/10.1046/j.1439-0523.1999.118002097.x

27. Musa, T., Hecker, A., Vogelgsang, S., \& Forrer, H. R. (2007). Forecasting of Fusarium head blight and deoxynivalenol content in winter wheat with FusaProg. EPPO Bulletin, 37(2), 283-289. https://doi.org/10.1111/j.1365-2338.2007.01122.x

28. Nakajima, T., Yoshida, M., \& Tomimura, K. (2008). Effect of lodging on the level of mycotoxins in wheat, barley, and rice infected with the Fusarium graminearum species complex. Journal of General Plant Pathology, 74(4), 289. https://doi.org/10.1007/s10327-008-0103-7

29. Palazzini, J. M., Alberione, E., Torres, A., Donat, C., Köhl, J., \& Chulze, S. (2016). Biological control of Fusarium graminearum sensu stricto, causal agent of Fusarium head blight of wheat, using formulated antagonists under field conditions in Argentina. Biological Control, 94, 56-61.

https://doi.org/10.1016/j.biocontrol.2015.12.009

30. Palazzini, J. M., Groenenboom de Haas, B. H., Torres, A. M., Köhl, J., \& Chulze, S. N. (2013). Biocontrol and population dynamics of Fusarium spp. on wheat stubble in Argentina. Plant Pathology, 62(4), 859-866. https://doi.org/10.1111/j.1365-3059.2012.02686.x

31. Palazzini, J. M., Ramirez, M. L., Torres, A. M., \& Chulze, S. N. (2007). Potential biocontrol agents for Fusarium head blight and deoxynivalenol production in wheat. Crop Protection, 26(11), 1702-1710. https://doi.org/10.1016/j.cropro.2007.03.004

32. Palfi, M., Vrandečić, K., Popijač, V., \& Čosić, J. (2019). Utjecaj eteričnih ulja na fitopatogene gljive. Poljoprivreda, 25(1), 32-40.

https://doi.org/10.18047/poljo.25.1.5

33. Poštić, J., Ćosić, J., Vrandečić, K., Jurković, D., Saleh, A. A., \& Leslie, J. F. (2012). Diversity of Fusarium species isolated from weeds and plant debris in Croatia. Journal of Phytopathology, 160(2), 76-81. https://doi.org/10.1111/j.1439-0434.2011.01863.x

34. Prandini, A., Sigolo, S., Filippi, L., Battilani, P., \& Piva, G. (2009). Review of predictive models for Fusarium head blight and related mycotoxin contamination in wheat. Food and Chemical Toxicology, 47(5), 927-931. https://doi.org/10.1016/j.fct.2008.06.010

35. Rossi, V., Giosuč, S., Pattori, E., Spanna, F., \& Del Vecchio, A. (2003). A model estimating the risk of Fusarium head blight on wheat. EPPO Bulletin, 33(3), 421-425. https://doi.org/10.1111/j.1365-2338.2003.00667.x

36. Schaafsma, A. W., \& Hooker, D. C. (2007). Climatic models to predict occurrence of Fusarium toxins in wheat and maize. International Journal of Food Microbiology, 119(1-2), 116-125. https://doi.org/10.1016/j.ijfoodmicro.2007.08.006

37. Schaafsma, A. W., Tamburić-llincić, L., \& Hooker, D. C. (2005). Effect of previous crop, tillage, field size, adjacent crop, and sampling direction on airborne propagules of Gibberella zeae/Fusarium graminearum, fusarium head blight severity, and deoxynivalenol accumulation in winter wheat. Canadian Journal of Plant Pathology, 27(2), 217-224. https://doi.org/10.1080/07060660509507219

38. Schisler, D. A., Khan, N. I., Boehm, M. J., \& Slininger, P J. (2002). Greenhouse and field evaluation of biological control of Fusarium head blight on durum wheat. Plant Disease, 86(12), 1350-1356. https://doi.org/10.1094/PDIS.2002.86.12.1350

39. Schisler, D. A., Khan, N. I., Boehm, M. J., Lipps, P. E., Slininger, P. J., \& Zhang, S. (2006). Selection and evaluation of the potential of choline-metabolizing microbial strains to reduce Fusarium head blight. Biological Control, 39(3), 497-506. https://doi.org/10.1016/j.biocontrol.2006.08.007

40. Shah, L., Ali, A., Yahya, M., Zhu, Y., Wang, S., Si, H., Rahman, H., \& Ma, C. (2018). Integrated control of fusarium head blight and deoxynivalenol mycotoxin in wheat. Plant Pathology, 67(3), 532-548. https://doi.org/10.1111/ppa.12785

41. Shi, C., Yan, P., Li, J., Wu, H., Li, O., \& Guan, S. (2014). Biocontrol of Fusarium graminearum growth and deo- 
xynivalenol production in wheat kernels with bacterial antagonists. International Journal of Environmental Research and Public Health, 11(1), 1094-1105. https://doi.org/10.3390/ijerph110101094

42. Siuda, R., Grabowski, A., Lenc, L., Ralcewicz, M., \& Spychaj Fabisiak, E. (2010). Influence of the degree of fusariosis on technological traits of wheat grain. International Journal of Food Science and Technology, 45(12), 2596-2604.

https://doi.org/10.1111/j.1365-2621.2010.02438.x

43. Steiner, B., Buerstmayr, M., Michel, S., Schweiger, W., Lemmens, M., \& Buerstmayr, H. (2017). Breeding strategies and advances in line selection for Fusarium head blight resistance in wheat. Tropical Plant Pathology, 42(3), 165-174.

https://doi.org/10.1007/s40858-017-0127-7

44. Stępień, Ł., \& Chełkowski, J. (2010). Fusarium head blight of wheat: pathogenic species and their mycotoxins. World Mycotoxin Journal, 3(2), 107-119. https://doi.org/10.3920/WMJ2009.1193
45. Strange, R. N., \& Smith, H. (1971). A fungal growth stimulant in anthers which predisposes wheat to attack by Fusarium graminearum. Physiological Plant Pathology, 1(2), 141-150. https://doi.org/10.1016/0048-4059(71)90023-3

46. Vrandečić, K., Jug, D., Čosić, J., Ilić, J., \& Jug, I. (2019). The impact of different conservation soil tillage and nitrogen fertilization on wheat grain infection with Fusarium sp. Poljoprivreda, 25(1), 26-31. https://doi.org/10.18047/poljo.25.1.4

47. Xu, X. M. (2003). Effects of environmental conditions on the development of Fusarium ear blight. European Journal of Plant Pathology, 109(7), 683-689. https://doi.org/10.1023/A:1026022223359

48. Zhao, Y., Selvaraj, J. N., Xing, F., Zhou, L., Wang, Y., Song, H., Tan, X., Sun, L., Sangare, L., Folly, Y. M. E., \& Liu, Y. (2014). Antagonistic action of Bacillus subtilis strain SG6 on Fusarium graminearum. PloS One, 9(3), 92486. https://doi.org/10.1371/journal.pone.0092486

\section{INTEGRATED PROTECTION OF WHEAT AGAINST Fusarium graminearum}

\section{SUMMARY}

Fusarium head blight (FHB) is an economically devastating disease that may exert an adverse impact on the wheat yield and quality. To date, no measure ensures a complete protection of wheat crops, but the combination of multiple protection measures may produce the promising results. The effectiveness of each measure is influenced by environmental conditions during the growing season and cultivar susceptibility to the FHB. The Integrated Pest Management (IPM) is the most effective approach to the management of FHB. For a successful control, it is essential to acquire a good knowledge of the pathogen, its life cycle, and its ecology. Since the F. graminearum is a predominant species causing the FHB on the wheat in Croatia, this paper aims to describe all available measures for its control.

Keywords: fusarium diseases, wheat, forecasting, biological control

(Primljeno 14. veljače 2020.; prihvaćeno 11. svibnja 2020. Received on February 14, 2020; accepted on May 11, 2020) 